Review

\title{
Combined Biogas and Bioethanol Production: Opportunities and Challenges for Industrial Application
}

\author{
Alessandra Cesaro * and Vincenzo Belgiorno \\ Sanitary Environmental Engineering Division (SEED), Department of Civil Engineering, \\ University of Salerno, via Giovanni Paolo II, 84084 Fisciano (SA), Italy; E-Mail: v.belgiorno@unisa.it \\ * Author to whom correspondence should be addressed; E-Mail: acesaro@unisa.it; \\ Tel.: +39-089-96-4181; Fax: +39-089-96-9620.
}

Academic Editor: Thomas E. Amidon

Received: 8 May 2015 / Accepted: 21 July 2015 / Published: 5 August 2015

\begin{abstract}
In the last decades the increasing energy requirements along with the need to face the consequences of climate change have driven the search for renewable energy sources, in order to replace as much as possible the use of fossil fuels. In this context biomass has generated great interest as it can be converted into energy via several routes, including fermentation and anaerobic digestion. The former is the most common option to produce ethanol, which has been recognized as one of the leading candidates to substitute a large fraction of the liquid fuels produced from oil. As the economic competitiveness of bioethanol fermentation processes has to be enhanced in order to promote its wider implementation, the most recent trends are directed towards the use of fermentation by-products within anaerobic digestion. The integration of both fermentation and anaerobic digestion, in a biorefinery concept, would allow the production of ethanol along with that of biogas, which can be used to produce heat and electricity, thus improving the overall energy balance. This work aims at reviewing the main studies on the combination of both bioethanol and biogas production processes, in order to highlight the strength and weakness of the integrated treatment for industrial application.
\end{abstract}

Keywords: anaerobic digestion; biorefinery; digestate; energy; fermentation; stillage 


\section{Introduction}

Since the middle of the last century energy demand has significantly increased as a result of both industrial development and population growth. Currently the basic energy requirements are largely met by the use of fossil fuels [1]. It has been recently reported that $80 \%$ of the global consumption of primary energy, of which $58 \%$ is taken up by the transport sector, is dependent on the use of fossil fuels [2]. As the production of energy from these fuels is associated to both resource depletion and climate change issues, the identification of new and renewable sources of energy has become a matter of priority in many countries [3].

Renewable energy is a resource that is naturally regenerated over a short time scale and derived from the sun, either directly (such as thermal, photochemical, and photoelectric energy) or indirectly (such as wind, hydropower, and photosynthetic energy stored in biomass), as well as from other natural movements and mechanisms of the environment, such as geothermal and tidal energy [4].

Among these renewable sources, biomass represents an essential substitute for fossil fuels and it has attracted great attention worldwide, contributing between $9 \%$ and $13 \%$ to the total global energy supply [5]. The term biomass refers to the biodegradable fraction of products, wastes and residues from agriculture, forestry and related industries. It also includes dedicated energy crops and trees [6]. In Europe energy from biomass is the fastest growing renewable energy source: its production almost doubled over the last decade and it currently supplies $6 \%$ of the total primary energy [7].

Biomass is indeed a versatile resource that can be converted to energy via several routes [8]. Some of the most relevant factors in choosing a specific conversion route are the nature of the feedstock, the availability of a given technology and the demand for a specific energy product [9]. The most common techniques can be broadly divided into thermochemical and biochemical processes.

Thermochemical conversion technologies rely on the thermal breakdown of biomass into fuels and valuable chemicals [10]. The process can occur via direct combustion [11], pyrolysis [12,13], gasification [14], torrefaction [15,16] and liquefaction [17,18].

Biochemical processes are based on different chemical reactions biologically catalysed by microorganisms and/or enzymes that convert fermentable substrates into fuels or other high-value products [19]. The most common types of biochemical processes are fermentation, as defined by Kumar et al. [20], and anaerobic digestion. The former uses microorganisms and/or enzymes to process a fermentable substrate, converting it into recoverable products: currently the most required fermentation product is ethanol [21]. Anaerobic digestion can be defined as the biological degradation of organic matter into biogas, which is mainly composed of methane and carbon dioxide; the process, occurring in an oxygen-free environment, has been largely applied to treat several kinds of biodegradable materials $[22,23]$.

Bioethanol, which is mainly produced from sugars and starch-rich materials, is one of the leading candidates to replace a large fraction of liquid fuels produced from oil. It can be used in mixtures up to $10 \%$ in gasoline without modification of the engines as well as in higher proportion in the so-called flexi-fuel vehicles, able to use up to $85 \%$ alcohol in mixtures with gasoline. Moreover, it is possible to use $100 \%$ bioethanol in specially designed engines [24-26]. Recently bioethanol has also been identified as one of the most promising bio-based raw materials for the chemical industry [27]. 
The economic feasibility of the bioethanol production process is tightly related to the market of its main by-product - distiller dried grains with solubles (DDGS) - as animal food: if the market of DDGS did not expand like that of ethanol, it would be an obstacle for the future large scale expansion of bioethanol production [28].

On the other hand, anaerobic digestion has been evaluated as one of the most efficient and sustainable processes for energy production [29]. Although it is not readily available as gaseous vehicle fuel, biogas can be easily utilized to produce heat and electricity, with minimal clean up after production [30].

The proper combination of both bioethanol and biogas production processes has been thus regarded as a suitable strategy to improve the competitiveness of fermentation plants, by producing both ethanol and biogas in a biorefinery concept. Such strategy pursues the combination of the material flows of different bio-industries, so that the residue from a bio-industry becomes the input of another one [31,32].

This work aims at reviewing main studies on the combination of bioethanol and biogas production processes. Both techniques are fully described and the feedstock characterization is discussed, in order to highlight its influence on the production of different types of energy. Main experimental results dealing with the use of fermentation by-products as anaerobic digestion substrates are compared, thus pointing out the strength and weakness of the combined process for industrial application.

\section{Bioethanol Production}

Bioethanol has been identified as the most widely used biofuel for transportation worldwide [33]. Its biochemical production involves at least the following stages: hydrolysis, fermentation, distillation and dehydration [34]. The biological degradation of biomass begins during the hydrolysis of complex molecules into simple compounds, which are readily available for the fermentation step. This natural pathway, depending on both operating conditions and raw material, is carried out by microorganisms that ferment sugars into alcohol, lactic acid or other end products. Bioethanol obtained from a fermentation process requires further treatment: to this end, fractional distillation is typically implemented to separate ethanol from water based on their different volatilities. Because the boiling point of water $\left(100^{\circ} \mathrm{C}\right)$ is higher than that of ethanol $\left(78.3^{\circ} \mathrm{C}\right)$, the ethanol-water mixture is boiled so that ethanol is converted to vapour before water. Then water can be separated via a condensation procedure and ethanol distillate is recaptured at a concentration of 95\% [35].

The efficient biochemical conversion of biomass to ethanol can be obtained via different technological options (Figure 1). Thus, the process success requires the combination of the most appropriate options at each step [36]. As a biological process, bioethanol fermentation is highly dependent on several factors, including $\mathrm{pH}$, oxygen and temperature, which can greatly influence the specific rate of growth. The viability of cell populations, the specific rate of fermentation and the sugar uptake rate are all directly related to the desired medium condition [37]. Similarly both process configuration and yeast strain play a fundamental role in the definition of fementation yields [38-41], along with the feedstock characteristics. 


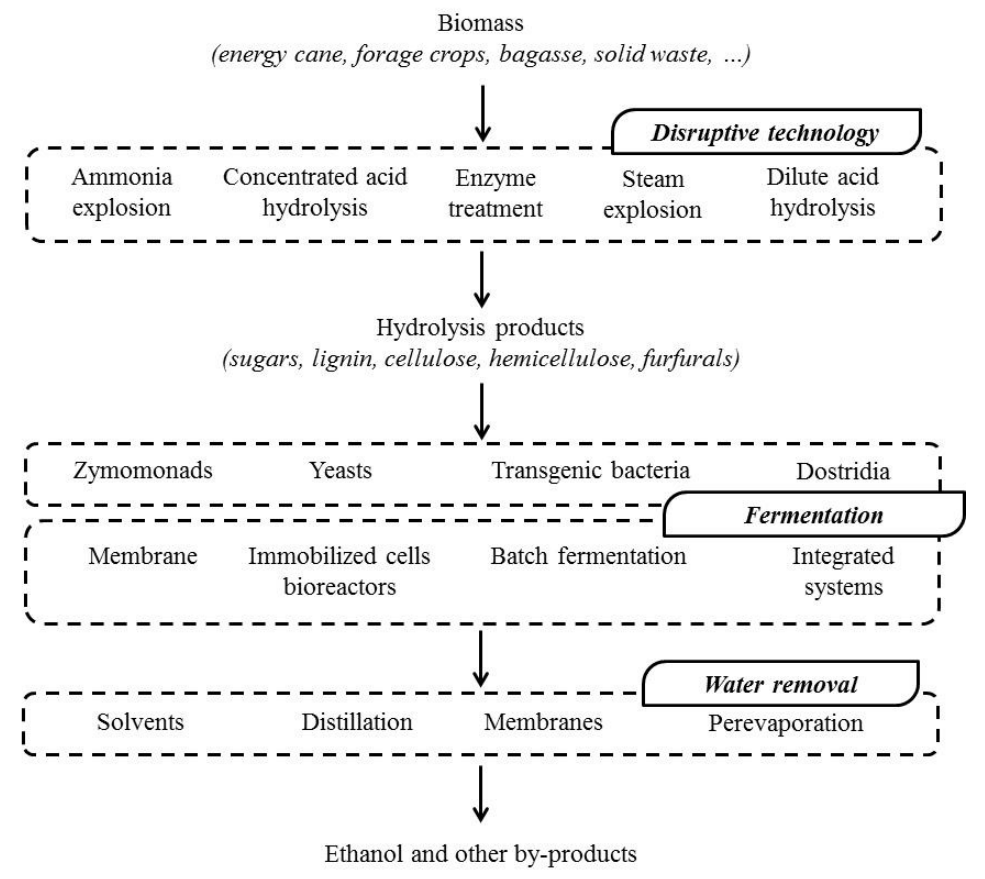

Figure 1. Biomass to ethanol conversion options, adapted by [36].

Bioethanol can be produced from the fermentation of different kinds of biomass. They are broadly classified as first generation materials (including starch and sugar) and second generation materials (lignocellulosic sugar). Currently the former are the most employed [42], but lignocellulosic materials, which are abundant and inexpensive, are gaining great interest [43].

The use of edible crops to produce the so-called first generation bioethanol has rightly been greatly criticized as an unsustainable technique, which poses the issues of both competition with food sources and disruption in the food-to-population ratio [44]. These concerns have driven the development of second-generation bioethanol that is derived from lignocellulosic wastes. More recently third generation bioethanol from alternative biomass such as microalgae and macroalgae has also generated significant interest [45]. The kind of substrate influences the whole bioethanol production process scheme.

For sucrose-based feedstocks such as molasses and sugarcane juice, processes like milling, pretreatment, hydrolysis, and detoxification are not necessary. Conversely most starch-based feedstocks and lignocellulose require some adequate pretreatment to be used for the production of fermentable sugar [46]. Lignocellulosic substrates are indeed composed of three materials: (i) cellulose, a sugar-based polymer; (ii) hemicelluloses, amorphous polysaccharides composed of different kinds of sugars, smaller than the ones of cellulose; (iii) lignin, which is a complex, aromatic polymer, mainly consisting of phenylpropane units [47]. Both hemicellulose and the amorphous portion of the cellulose can be easily hydrolysed, while crystalline cellulose is resistant to bioconversion [48]. This aspect explains the need for pretreatment, which is necessary to provide adequate structural modification of lignocellulosic substrates, in order to increase cellulose enzymatic digestibility yields. Once being accessible, cellulose is hydrolysed into glucose and hemicellulose is converted into both pentoses (C5 sugars) and hexoses (C6 sugars). Differently from anaerobic digestion, the fermentation efficiency varies for these sugar fractions $[49,50]$, so that separate pathways have been studied to optimize techno-economics of ethanol production from lignocellulosic biomass utilization [51]. 


\section{Biogas Production}

The biochemical degradation of organic substrates to biogas has been a promising option due to its economic and environmental feasibility compared to other biofuels [52]. Anaerobic digestion is a biological process occurring through defined steps. The first stage is the hydrolysis of complex organics (i.e., carbohydrates, lipids and proteins) into soluble compounds; it is recognized as the process rate limiting step, so that it is often promoted by adequate substrate pretreatment [53].

The hydrolysed organic compounds (monomeric sugars, amino-acids and fatty acids) are utilized by acidogenic (acid-forming) bacteria for their growth and accumulate volatile fatty acids (VFAs) during the so-called acidogenesis step. VFAs are then transformed by acetogenic bacteria into simpler products, including acetic acid, hydrogen and carbon dioxide, during the step known as acetogenesis. These products are finally converted into methane by methanogens [54].

Anaerobic digestion yields depend on several factors [55,56], including temperature [57-60], organic loading rate [61-64] and substrate to inoculum ratio [65-67]. Under similar operating conditions, substrate characteristics play a key role in defining the amount of biogas that can be recovered by anaerobic digestion, as the theoretical gas yield varies with substrate composition in terms of carbohydrates, proteins and fats, as given in Table 1.

Substrates highly rich in lipids and easily-degradable carbohydrates exhibit higher methane potential than lignocellulosic materials [68]. These are more recalcitrant to the biological degradation, due to the presence of lignin $(10 \%-25 \%)$, which is the main constituent along with cellulose $(35 \%-50 \%)$ and hemicellulose $(20 \%-35 \%)$. The amount of lignin, cellulose and hemicellulose varies between different biomass species as well as due to growth conditions and maturation [69]. However, it should be pointed out that the real methane production is generally higher than the one theoretically estimated, because part of the carbon dioxide, which is the main component of biogas along with methane, is solubilized in the digestate.

Table 1. Maximal theoretical methane yields for substrate constituents, adapted from [29].

\begin{tabular}{cc}
\hline Constituent & Methane yield $\left[\mathbf{N m}^{3} / \mathbf{t}_{\mathbf{T S}}\right]$ \\
\hline Carbohydrates & $395-400$ \\
Raw protein & 497 \\
Raw fat & $816-850$ \\
Lignin & 0 \\
\hline
\end{tabular}

Table 2 reports the composition of selected kinds of biomass in terms of lignocellulosic constituents as well as their methane potential. Despite the relevant presence of lignin, some of these biomasses show methane potentials comparable to those reported for energy crops [70], organic waste [71] and other substrates conventionally used within industrial scale anaerobic digestion facilities. This evidence indicates by far the great energetic potential of these organic materials. 
Table 2. Composition and methane yields of selected kinds of biomass.

\begin{tabular}{cccccc}
\hline Biomass & $\begin{array}{c}\text { Cellulose } \\
{[\%]}\end{array}$ & $\begin{array}{c}\text { Hemicellulose } \\
{[\mathbf{\%}]}\end{array}$ & $\begin{array}{c}\text { Lignin } \\
{[\mathbf{\%}]}\end{array}$ & $\begin{array}{c}\text { Methane potential } \\
{\left[\mathbf{N m}_{\mathbf{C H} 4} / \mathbf{t}_{\mathbf{v s}}\right]}\end{array}$ & Ref. \\
\hline Bagasse & 38.2 & 27.1 & 20.2 & $\mathrm{NA}$ & {$[69]$} \\
Barley straw & $37.5-45$ & $24.2-31.7$ & $9.0-26.1$ & 226.4 & {$[69,72,73]$} \\
Corn stover & $33.7-41.3$ & 22.4 & $15.2-18.6$ & $80-157.3$ & {$[69,74]$} \\
Eucalyptus & $38.0-45.0$ & $12.0-13.0$ & $25.0-37.0$ & $\mathrm{NA}$ & {$[69]$} \\
Leaves & $11.1-12.2$ & - & $22.7-23.1$ & $47-75$ & {$[69,74]$} \\
Maize & 37.5 & 30.0 & 10.3 & 418 & {$[70,75]$} \\
Pine wood & $26.0-44.15$ & 30.5 & $24.3-28.3$ & 20 & {$[69,74,76]$} \\
Rice straw & $32.0-39.6$ & $18.5-24.0$ & $13.0-22.7$ & 302 & {$[69,70,77]$} \\
Sorghum & 22.2 & 19.4 & 21.4 & $286-319$ & {$[69]$} \\
Sugarcane & 25.0 & $16.8-32.2$ & $12.0-31.4$ & 278 & {$[69,70,78]$} \\
Sunflower stalk & 31.0 & 15.6 & 29.2 & $231-297$ & {$[69]$} \\
Switch grass & $31.0-45.0$ & $20.0-31.0$ & $12.0-18.0$ & 125 & {$[69,74]$} \\
Wheat straw & $32.3-37.9$ & $21.2-25.8$ & $8.3-23.4$ & $130-290$ & {$[69,70,74,79]$} \\
\hline
\end{tabular}

\section{The Combination of Bioethanol and Biogas Production Processes}

Ethanol and biogas are industrially produced from the same kinds of easily degradable biomass resources [80], so that the question of producing either bioethanol or biogas from a given substrate has been already debated. Although the use of sugar-/starch-rich energy crops has been reported to be energetically effective to produce methane rather than ethanol, Moshi et al. [81] concluded that each of these products may be more appropriate than the other depending on both the area of application and existing infrastructure. However, if anaerobic digestion is a well-established technology, fermentation spread is often limited due to operating costs [82], mainly related to the high energy requirements as well as to the management of by-products. It has been estimated that a typical dry milling ethanol plant can roughly produce $40.2 \mathrm{~L}$ of ethanol and $32.1 \mathrm{~kg}$ of DDGS per $100 \mathrm{~kg}$ of corn used [83].

The proper combination of bioethanol and biogas production processes can be regarded as a suitable option to attain a greater bioenergy potential from biomass, thus improving both the mass and energy balances of single processes and, in particular, that of bioethanol production plants.

Stillage, which is the main fermentation by-product, is indeed characterized by high COD values, variable according to the feedstock used for bioethanol production (Table 3), as well as to the operating conditions of ethanol production process. Such COD values are comparable with the ones of other organic materials typically used as anaerobic digestion substrate [84-86], pointing out stillage organic potential to be transformed into methane. 
Table 3. Characteristics of stillage from the fermentation of different biomasses.

\begin{tabular}{cccccc}
\hline Biomass & $\mathbf{p H}[-]$ & TS [\%] & COD $[\mathbf{g} / \mathbf{L}]$ & Soluble COD $[\mathbf{g} / \mathbf{L}]$ & Ref. \\
\hline Bagasse & - & 6.89 & - & 38.6 & {$[87]$} \\
Barley & 4.2 & 5.97 & 29.5 & - & {$[88,89]$} \\
Beet molasses & $4.3-6.7$ & - & $55.5-147$ & - & {$[89]$} \\
Cassava & 4.08 & 6.05 & 101.2 & 32.5 & {$[90]$} \\
Corn stover & 4.4 & $6.2-7.7$ & 74.8 & 73.9 & {$[91,92]$} \\
Maize & 3.7 & $3.7-7.5$ & $21.85-59.4$ & - & {$[93]$} \\
Sugarcane & $3.9-4.6$ & - & $31.5-45$ & - & {$[94]$} \\
Sweet sorghum & 4.5 & - & 79.9 & - & {$[89]$} \\
Wheat straw & 3.6 & 12.0 & $150-154.2$ & $61-76.8$ & {$[95,96]$} \\
\hline
\end{tabular}

Anaerobic digestion can thus convert over $50 \%$ of the by-product COD to biogas, which may be used as fuel within the plant [89]. Moreover, as stillage represents the partially degraded form of the biomass used within the fermentation process, the energy required for its treatment prior to anaerobic digestion can be significantly reduced [97]. Several studies reported the use of bioethanol residues for biogas production. Most of them were carried out to explore the methane potential of stillage originating from corn and grain bioethanol production processes, as reported in Table 4.

Table 4. Anaerobic processing of different bioethanol residues.

\begin{tabular}{|c|c|c|c|}
\hline Stillage & AD operating conditions & Highlights & Reference \\
\hline Algae & $\begin{array}{l}\text { Batch tests (60 mL working volume); } \\
\qquad \mathrm{T}=35^{\circ} \mathrm{C}\end{array}$ & $\begin{array}{l}\text { Methane yields in the range } 239-283 \mathrm{~L} / \mathrm{kgvs} \text {, } \\
\text { corresponding to energy potential } 2.24 \text { times } \\
\text { higher than that from the ethanol produced in the } \\
\text { main process. }\end{array}$ & [98] \\
\hline Algae & $\begin{array}{l}\text { Batch tests (100 } \mathrm{mL} \text { working volume); } \\
\qquad \mathrm{T}=35^{\circ} \mathrm{C} ; \\
\text { Inoculum as } 4.5 \text { and } 20 \mathrm{~g} \text { vss } / \mathrm{L}\end{array}$ & $\begin{array}{l}\text { The inhibition by dilute-acid hydrolysis } \\
\text { byproduct was overcome by increasing } \\
\text { inoculum concentration. } \\
\text { Under optimal tested condition, } 84.8 \% \text { methane } \\
\text { conversion rate was achieved. }\end{array}$ & [99] \\
\hline Cassava & $\begin{array}{l}\text { CSTR batch tests }\left(37^{\circ} \mathrm{C} \text { and } 60^{\circ} \mathrm{C}\right) \\
\text { converted into semi-continuous }\left(37^{\circ} \mathrm{C}\right)\end{array}$ & $\begin{array}{l}\text { Under OLR higher than } 10 \mathrm{gvs} / \mathrm{L} \mathrm{d} \text {, the } \\
\text { two-phase thermophilic CSTR was stable with } \\
\text { hydrogen and methane yields of } 56.6 \mathrm{mLH} / \mathrm{gvs} \\
\text { and } 249 \mathrm{mLCH} / \mathrm{gvs} \text {, respectively. }\end{array}$ & {$[100]$} \\
\hline Cereal & $\begin{array}{c}\text { Semi-continuous CSTR }(5 \mathrm{~L}) ; \\
\mathrm{T}=35^{\circ} \mathrm{C} \text {. Manure used as co-substrate } \\
(15 \% \text { based on VS })\end{array}$ & $\begin{array}{l}\text { Anaerobic digestion of whole stillage turned to } \\
\text { instability after } 120 \text { days of operation. Co-digestion } \\
\text { with manure improved process stability and } \\
\text { methane yield compared with theoretical values. } \\
\text { The AFBR showed up to } 88 \% \text { TCOD and } 78 \%\end{array}$ & {$[101]$} \\
\hline Corn & $\begin{array}{l}\text { Anaerobic fluidized bed bioreactor (AFBR) } \\
\text { employing zeolite as the carrier media; } \\
\qquad \mathrm{T}=37^{\circ} \mathrm{C}\end{array}$ & $\begin{array}{l}\text { TSS removal at OLR of } 29 \mathrm{~kg} \mathrm{COD} / \mathrm{m}^{3} \mathrm{~d} \text { and } \\
\text { HRT of } 3.5 \text { days. } \\
\text { Methane production rates of up to } 40 \mathrm{~L} / \mathrm{L} \text { stillage } \mathrm{d} \\
\text { was reached at the steady state. }\end{array}$ & {$[102]$} \\
\hline Corn & $\begin{array}{l}\text { BMP assays with alkalinity adjustment; } \\
\qquad \mathrm{T}=35^{\circ} \mathrm{C} \text { and } 55^{\circ} \mathrm{C}\end{array}$ & $\begin{array}{l}\text { Methane potential up to } 1 \mathrm{~L} / \mathrm{g}_{\mathrm{vs}} \text {, with the best } \\
\text { performances under thermophilic conditions. }\end{array}$ & [103] \\
\hline
\end{tabular}


Table 4. Cont.

\begin{tabular}{|c|c|c|c|}
\hline Stillage & AD operating conditions & Highlights & Reference \\
\hline$?$ & $\begin{array}{l}\text { Semi continuous tests at SRT of } 60,45 \text { and } \\
35 \text { days; } \mathrm{T}=35^{\circ} \mathrm{C} \text { and } 55^{\circ} \mathrm{C}\end{array}$ & $\begin{array}{l}\text { Thermophilic digester was unable to cope with } \\
\text { high organic loading rate at SRT of } 60 \text { days, } \\
\text { whereas under mesophilic conditions, the } \\
\text { digester was stable with } 58 \mathrm{~L}_{\mathrm{CH} 4} / \mathrm{kg} \text { stillage. }\end{array}$ & \\
\hline Corn & $\begin{array}{l}\text { BMP assays with alkalinity adjustment; } \\
\qquad \mathrm{T}=35^{\circ} \mathrm{C} ; \\
\text { ISR: } 3.67-0.46 \mathrm{~g} / \mathrm{g}\end{array}$ & $\begin{array}{l}\text { At the organic loading rate of } 0.46 \mathrm{~g} / \mathrm{g} \text {, } \\
\text { degradation was completed in } 15-16 \text { days. } \\
\text { Methane potential in standard conditions was } \\
\text { found in the range } 401-458 \mathrm{~mL} / \mathrm{g} \text { vs added, with } \\
\text { organic removals between } 76 \% \text { and } 94 \% \text { in } \\
\text { batch mode. }\end{array}$ & {$[104]$} \\
\hline Corn & $\begin{array}{l}\text { Batch test }(250 \mathrm{~mL}) ; \mathrm{T}=35^{\circ} \mathrm{C} \text {; } \\
\text { ISR: } 0.5-3.0 \mathrm{gvs} / \mathrm{g}_{\mathrm{vs}} ; \\
\text { Mechanically shaking provided }\end{array}$ & $\begin{array}{l}\text { Thin stillage, treated by centrifugation and lime } \\
\text { addition, resulted in rapid production of high } \\
\text { levels of biogas ( } 763 \mathrm{~mL} \text { biogas } / \mathrm{gvs}_{\text {added }} \text {, } \\
\text { under the optimal ISR of } 2.0 \mathrm{gvs} / \mathrm{gvs.}\end{array}$ & {$[105]$} \\
\hline Corn & $\begin{array}{c}\text { Batch tests; } \mathrm{T}=35^{\circ} \mathrm{C} ; \\
\text { Substrate/inoculum ratios: } 4-8 \mathrm{~g}_{\mathrm{TCOD}} / \mathrm{g}_{\mathrm{VSS}}\end{array}$ & $\begin{array}{c}\text { Two-stage process enabled } 18.5 \% \text { increase in } \\
\text { total energy yield. }\end{array}$ & {$[106]$} \\
\hline Corn & $\begin{array}{l}\text { Batch tests (2.8 L working volume); } \\
\qquad \mathrm{T}=35^{\circ} \mathrm{C}\end{array}$ & $\begin{array}{l}\text { Anaerobic digestion of corn stillage was able to } \\
\text { improve the overall content utilization and } \\
\text { extract a greater yield of lignocellulosic biomass } \\
\text { compared to ethanol fermentation alone. }\end{array}$ & [107] \\
\hline Grain & $\begin{array}{c}\text { Continuous UASB reactor } \\
\text { (working volume of } 255 \mathrm{~mL} \text { ); } \\
\text { HRT }=48 \mathrm{~h} ; \mathrm{T}=55^{\circ} \mathrm{C}\end{array}$ & $\begin{array}{l}\text { Maximum methane yield of } 155 \mathrm{ml} / \mathrm{g}_{\mathrm{COD}} \text { was } \\
\text { obtained at stillage mixtures with water of } 25 \% \\
(\mathrm{v} / \mathrm{v}) \text { in the feed and at an OLR of } 17.1 \mathrm{gCOD} / \mathrm{L} \mathrm{d} \text {. }\end{array}$ & [95] \\
\hline Grain & $\begin{array}{l}\text { CSTR (5 L), FBR (12.9 L) and ASBR }(13 \mathrm{~L}) ; \\
\qquad \mathrm{T}=38^{\circ} \mathrm{C} ; \\
\text { OLR up to } 10 \mathrm{gVs} / \mathrm{L} \mathrm{d}\end{array}$ & $\begin{array}{l}\text { At HRT as low as } 6 \text { days, good performances } \\
\text { can be achieved by continuous grain anaerobic } \\
\text { digestion when trace elements are supplemented, } \\
\text { despite the reactor system. }\end{array}$ & [108] \\
\hline Grain & $\begin{array}{l}\text { Semi continuous CSTR digester; } \\
\qquad \begin{array}{l}\mathrm{T}=38^{\circ} \mathrm{C} \text { and } 44{ }^{\circ} \mathrm{C} \\
\text { OLR up to } 6 \mathrm{gvs}_{\mathrm{V}} / \mathrm{L} \mathrm{d}\end{array}\end{array}$ & $\begin{array}{l}\text { Operation at } 44{ }^{\circ} \mathrm{C} \text { was the most successful } \\
\text { strategy, resulting in up to } 22 \% \text { higher methane } \\
\text { yield compared with the mesophilic reactor. }\end{array}$ & [109] \\
\hline Grain & $\begin{array}{c}\text { CSTR digester }(12 \mathrm{~L}) ; \mathrm{T}=35{ }^{\circ} \mathrm{C} ; \\
\mathrm{OLR}=10 \mathrm{gVs} / \mathrm{L} \mathrm{d} ; \mathrm{HRT}=7-8.5 \text { days }\end{array}$ & $\begin{array}{l}\text { The depletion of } \mathrm{Fe} \text { and } \mathrm{Ni} \text { resulted in a rapid } \\
\text { accumulation of volatile fatty acids while Co and } \\
\text { W seem to have a long-term effect. }\end{array}$ & {$[110]$} \\
\hline Grain & $\begin{array}{l}\text { Semi continuous CSTR digester } \\
\text { (4 L working volume); } \mathrm{T}=35^{\circ} \mathrm{C} ; \\
\mathrm{OLR}=2.5 \text { and } 4 \mathrm{gvs} / \mathrm{L} \mathrm{d}\end{array}$ & $\begin{array}{l}\text { The solubility and speciation of supplemented Fe } \\
\text { were controlled by precipitation of } \mathrm{FeS}(\mathrm{s}) \text { and } \\
\text { formation of the aqueous complexes of } \\
\text { Fe-sulfide and Fe-thiol. }\end{array}$ & [111] \\
\hline Kitchen garbage & $\begin{array}{l}\text { Semi continuous CSTR digester } \\
(8 \mathrm{~L} \text { working volume) with biogas } \\
\text { recirculation; } \mathrm{T}=53^{\circ} \mathrm{C} \text { and } 60^{\circ} \mathrm{C} ; \\
\qquad \mathrm{OLR}=7 \mathrm{gvs} / \mathrm{L} \mathrm{d}\end{array}$ & $\begin{array}{l}\text { A biogas recirculation ratio of } 150 \text { facilitated } \\
\text { stable digestion performance and biogas } \\
\text { production, while the ammonia removal } \\
\text { efficiency increased } 1.23 \text {-fold when the } \\
\text { temperature increased from } 53^{\circ} \mathrm{C} \text { to } 60^{\circ} \mathrm{C} \text {. }\end{array}$ & [112] \\
\hline $\begin{array}{l}\text { Sugarcane } \\
\text { bagasse }\end{array}$ & BMP assay, $55^{\circ} \mathrm{C}$ & $\begin{array}{l}\text { Methane potential over } 80 \text { days was } \\
\text { approximately } 10 \mathrm{~mL}_{\mathrm{CH} 4} / \mathrm{mL}_{\text {stillage, with } 85 \% \text { of }} \\
\text { ultimate methane yield produced in } 50 \text { days. }\end{array}$ & [87] \\
\hline
\end{tabular}


Corn and grain can be classified as starch-based materials. Their widespread use in biomass-to-ethanol processes [46,113] results in the availability of great amount of both corn- and grain-based stillage. Eskicioglu et al. [103] evaluated the anaerobic potential of whole stillage from a dry-grind corn-based ethanol plant by continuous-flow digesters under both thermophilic and mesophilic conditions. They found that mesophilic digestion at 60 days of sludge retention time (SRT) provided a methane yield of $58 \mathrm{~L} / \mathrm{kg}$ stillage, but the best performances were observed under thermophilic conditions. Further studies [104] pointed out that the ultimate methane yield of corn stillage was not affected by inoculum to substrate ratio (ISR), which influenced the content of methane in biogas: the higher was ISR, the lower was the percentage of methane in biogas. Similar results were obtained by Alkan-Ozkaynak and Karthikeyan [105]. They studied the effect of ISR in the range $0.5-3 \mathrm{gvs} / \mathrm{g}_{\mathrm{VS}}$ on the methane potential of centrifuged and lime-treated corn stillage. The rapid initial biogas production at all the ISR levels tested confirmed that the biomass was well acclimated to the treated-thin stillage. The maximum net biogas production followed then the decreasing order: ISR $1>$ ISR $2>$ ISR $0.5>$ ISR 3 . In reactors operating with an ISR of $0.5 \mathrm{gvs} / \mathrm{gvs}$, despite the high initial VS amount added, no significant biogas production was observed after 2.5 days. This outcome was ascribed to the rapid formation of intermediate products, as indicated by the final $\mathrm{pH}$ values that were in the acidic range. The best performances both in terms of biogas production $(763 \mathrm{~mL} / \mathrm{gvs}$ added $)$ and organic matter removal $(80.6 \%$ COD) were achieved with an ISR of 2 gvs/gvs. The study also highlighted that, under the same operating conditions, pretreated thin stillage resulted in higher biogas production than untreated samples. This evidence was attributed to the removal of some potentially toxic components, such as long-chain fatty acids.

Pretreatments represent by far the most widespread strategy to overcome the limits of the hydrolysis of complex organic molecules to soluble substrates. Their application has thus been broadly studied to enhance anaerobic digestion yields and several research attempts have also dealt with the pre-processing of substrates destined to bio-ethanol production. In this view, the work of Wang et al. [107] is particularly interesting. The authors treated chopped corn by steam explosion, performed at $2.0 \mathrm{MPa}$ for $5 \mathrm{~min}$. The feedstock was then dried at room temperature up to $92 \% \mathrm{TS}$ and fed to a $2 \mathrm{~L}$ batch reactor for a simultaneous enzymatic saccharification fermentation process. The resulting stillage was used to perform both BMP assays and anaerobic digestion tests. Both pretreatment and hydrolytic enzyme action determined the release of easily digestible compounds. The ready bioavailability of these compounds promoted fast methane production, which reaches its peak value during the first 2 days. The overall product yield was $197 \mathrm{~g}$ ethanol and $96 \mathrm{~g}$ methane/ $\mathrm{kg}$ corn stover: thus methane production involved $9.6 \%$ improvement in the conversion of corn stover to energy. Consistent results were obtained by using bioethanol fermentation residues from steam exploded oat straw as anaerobic digestion substrate [114]. Biogas production rate from the fermentation residues was found to be higher than the one obtained from the steam exploded oat straw that had not undergone the bioethanol production process. This evidence suggests that the ethanol process offered an additional pretreatment for the biogas process.

Pretreatments can enhance biological process yields by simplifying the molecular structure of organic substrates, as difficult-to degrade fractions obviously provide a lower contribution to either ethanol or biogas production. Tian et al. [87] tested the products of bagasse stillage screening for their methane potential and compared these results to the methane potential of the whole stillage. The filtrate, which is the stillage fraction passing through $0.5 \mathrm{~mm}$ screen, was found to contribute by $70 \%$ to the whole stillage methane potential. When fed to a $15 \mathrm{~L}$ semi-continuous anaerobic digester, stillage filtrate determined 
approximately $80 \%$ COD removal. Based on these results, it was estimated that the anaerobic digestion of bagasse stillage filtrate can cover $62 \%$ of the energy consumed by ethanol distillation. The main drawback of treating only stillage filtrate by anaerobic digestion lays in the need for a proper strategy to manage the filtration residues, which were found to have relatively low methane potential.

This aspect is particularly relevant when the feasibility of an integrated bioethanol/biogas production process is considered. The disposal of residues can indeed result in additional costs which could make the process itself not sustainable. The integrated bioethanol/anaerobic digestion process optimization not only in terms of net energy gain, but also with reference to mass flows is, therefore, fundamental. In this view Zhang et al. [115] used the stillage from pretreated cassava to feed a thermophilic UASB reactor with $10 \mathrm{~L}$ working volume. The resulting digestion liquid was centrifuged and the supernatant was put into a mesophilic UASB reactor (10 L working volume). The digestion liquid flowing out of the mesophilic UASB was finally mixed with the raw materials for next batch of ethanol fermentation. The introduction of the two-stage anaerobic process allowed full stillage recycling to the ethanol fermentation step, with the consequent optimization of the process mass balance. Experimental results showed that the presence of potentially inhibitory substances (i.e., organic compounds, VFAs, ions and colorants) reached a relative steady state after 3-7 batches recycling, without producing any negative effect on ethanol fermentation.

The use of a two-stage anaerobic process is a further option to enhance the recovery of stillage energetic potential. The separation of the acidogenic step from the methanogenic one results in enhanced stability to the different groups of microorganisms as well as in a better process control [116]. Nasr et al. [106] compared one-stage and two-stage anaerobic digestion processes for the treatment of thin stillage. The separation of acidogenesis and methanogenesis allowed a maximum methane yield of $0.33 \mathrm{~L} / \mathrm{gCOD}$ added and an overall increase of $18.5 \%$ in the energy yield.

In the context of stillage anaerobic digestion optimization, several studies have been performed to assess the influence of reactor configuration [95,100,102]. At full-scale excellent performances and high process stability were achieved by a FBR treating the stillage originating from sweet potato-shochu production [117].

However the comparison of Continuous Stirred Tank Reactor (CSTR), Fixed Bed Reactor (FBR), and Anaerobic Sequencing Batch Reactor (ASBR), operating under mesophilic conditions and with OLR up to $10 \mathrm{~g} / \mathrm{L} \mathrm{d}$, showed no significant differences [108]. Even the CSTR system, which was different from the other kinds of reactor (Figure 2) as it run without biomass immobilization, was able to provide a stable process at HRT values lower than 10-14 days.

Process stability maintenance is the most important aspect when anaerobic digestion has to be applied on a full scale. This ensures high methane production and the proper economic feasibility of the process.

Bioethanol residues are usually characterized by a prevailing protein content. The anaerobic digestion of these residues can thus suffer from ammonia inhibition [118]. In order to face this drawback, the effect of increasing organic loading rate (up to $6.0 \mathrm{gvs} / \mathrm{L} \mathrm{d}$ ) and simultaneously decreasing hydraulic retention time (down to 24 days) was investigated [109]. The substrate was a mixture of thin stillage and milled grain and it was characterized by an ammonia-nitrogen level ranging between 689 and $984 \mathrm{mg} / \mathrm{kg}$. The anaerobic process was performed in continuously stirred tank laboratory reactors, operating at both $38{ }^{\circ} \mathrm{C}$ and $44^{\circ} \mathrm{C}$. The thermophilic process at low HRT proved to be the most successful. Thermophilic operation would further improve the overall energy balance of the combined bioethanol/anaerobic 
digestion process because it would not require the cooling of the fed stillage, typically characterized by temperature values around $70^{\circ} \mathrm{C}$.

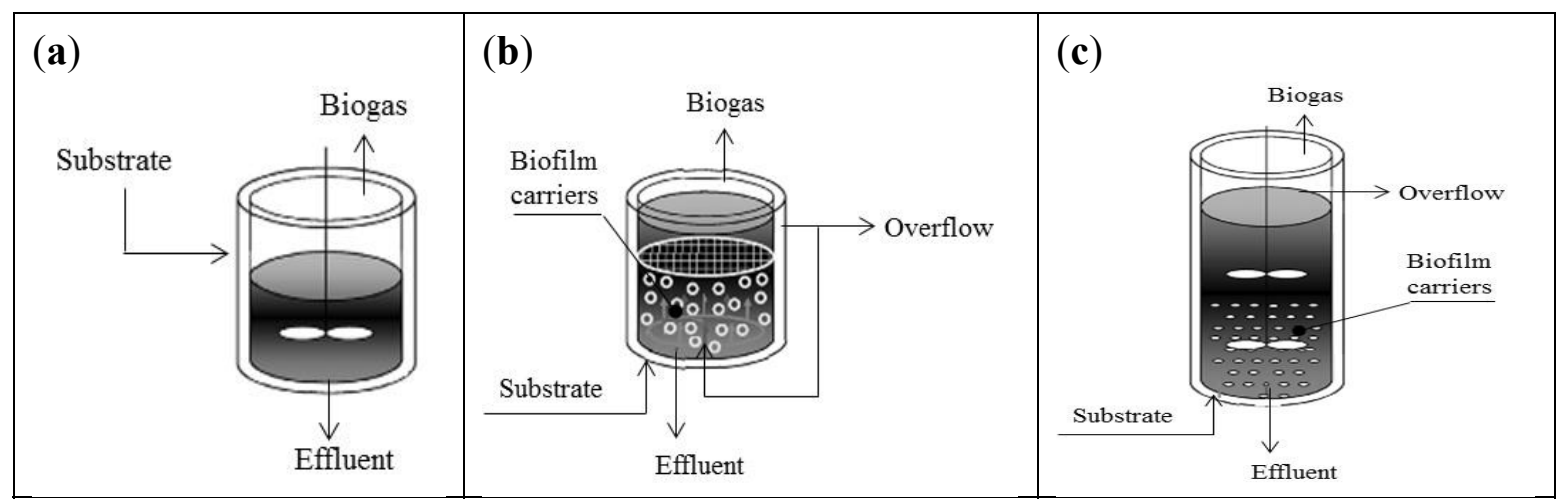

Figure 2. Reactor configuration, adapted from Schmidt et al. [108]. (a) Continuous Stirred Tank Reactor (CSTR). (b) Fixed Bed Reactor (FBR). (c) Anaerobic Sequencing Batch Reactor (ASBR).

A thermophilic process was investigated along with biogas recirculation as another option to optimize the anaerobic digestion of nitrogen-rich stillage [112], obtained from garbage bio-ethanol production. Anaerobic digestion tests were performed in an $8 \mathrm{~L}$ working volume CSTR, with OLR up to $7 \mathrm{gvs} / \mathrm{L} \mathrm{d}$, at temperature of $53{ }^{\circ} \mathrm{C}$ or $60{ }^{\circ} \mathrm{C}$. Biogas was recirculated into either the headspace of the reactor or the liquid phase of the reactor, varying the recirculation ratio in the range 10-150. Micro-aeration was also provided by continuously supplying ambient air at 3\% of the amount of produced biogas in order to reduce the $\mathrm{H}_{2} \mathrm{~S}$ content in the biogas itself. The best performances were obtained in the system where biogas was recirculated at the highest investigated ratio (150) into the reactor headspace. At $60{ }^{\circ} \mathrm{C}$ process stability could be ensured even lowering the recirculation ratio to 10 or 50 , thus suggesting that the simplification of system operation could be achieved.

Although ammonia inhibition is a quite common drawback of stillage anaerobic digestion, sulfur presence can also occur as a cause of instability. Sulphur-rich stillage, like the one originating from wheat, can be difficult to digest, as both $\mathrm{H}_{2} \mathrm{~S}$ production and metal sulfide precipitation in the digester can limit methanogenesis. However, it has been reported that even when sulphur concentrations are higher than metal ones, precipitated metal sulfides can act as a source of trace metals which do not inhibit methanogenesis. Following this statement, Schmidt et al. [110] developed a dosing strategy of trace metals in wheat stillage anaerobic digestion. To this end, CSTR systems were semi-continuously fed under mesophilic conditions, at an OLR of $10 \mathrm{gvs} / \mathrm{L} \mathrm{d}$ and HRT varying between 7 and 8.5 days. Trace elements were daily provided to the substrates. Results showed that cobalt (Co) and tungsten (W) had long-term effects on the anaerobic process. Therefore their dosing can be less frequent, with consequent economic benefits. Conversely iron (Fe) and nickel (Ni) depletion resulted in a rapid accumulation of volatile fatty acids and Fe deficiency was found to affect not only methane production but also propionate oxidation. Trace metals need to be properly supplied to limit inhibition phenomena, but their role within anaerobic process also depends on their solubility and bioavailability. Further studies demonstrated that these properties are influenced by complex reactions that involve both inorganic bisulfide (HS ${ }^{-}$) and organic thiol moieties [111]. 
Supplying trace metals can thus play a key role in the anaerobic digestion of stillage. However from a technical point of view, the addition of these substances can prove to be not economically feasible, especially when considering full-scale operation.

A viable alternative can be recognized in stillage anaerobic co-digestion, which is the simultaneous digestion of stillage with two or more substrates [119]. Such process allows the macro- and micro-nutrients equilibrium, moisture balance and promotes the dilution of potentially inhibitory compounds, thus improving methane yields [120]. However the main reason of anaerobic co-digestion success has been recognized in the high OLR that can be applied to the digesters. In this view all kinds of feedstock can be digested within the same industrial process [121].

Whole stillage and manure co-digestion significantly improved biogas productivity and process stability. Methane yield was found to be higher than $20 \mathrm{~m}^{3} / \mathrm{m}^{3}$ of biomass, which is recognized as the level required for anaerobic digestion to be economically feasible [101]. Similar results were also obtained in other studies [90,122-124].

Although it is not as widespread as corn and grain, the use of algae as bioethanol feedstock is gaining increasing attention [125]. The algal ethanol production residue has been reported to be a suitable anaerobic digestion feedstock. It can retain up to $70 \%$ of algal biomass as energy basis and it can produce energy up to 2.24 times higher than that of ethanol production in the main process [98]. On the other hand, one of the by-products of algae utilization for ethanol production can limit the subsequent anaerobic digestion process. Inhibitory effects were also observed during the anaerobic digestion of red algal ethanol fermentation residues but, in this case, increasing inoculum concentration was found to be the solution [99].

The use of stillage as anaerobic digestion feedstock is thus a suitable strategy to improve the competitiveness of bioethanol fermentation plants. Several technological solutions can be considered but, among the issue to be solved, there is the management of the residues originating from the combined bioethanol/anaerobic digestion process, so that further research should be performed, in order to address the optimization of both mass and energy balances.

Literature analysis also pointed out that the combination of bioethanol and biogas production processes, at both research and industrial level, mainly rely on the use of corn and grain as feedstocks. Few reports deal with the use of lignocellulosic substrates for the production of both ethanol and methane [126-128], but up-scale attempts have already been provided in this field.

Based on previous lab-scale works [129], a biorefinery concept for the production of both second generation ethanol and biogas was developed at pilot-scale. The process included: (i) a wet explosion pretreatment of lignocellulosic substrate; (ii) its enzymatic hydrolysis and fermentation of the C6 sugars, after which lignin was separated, and (iii) a separate C5 sugar fermentation into ethanol. The residual stream from ethanol production became the input flow to an anaerobic process performed in a UASB reactor, under both mesophilic and thermophilic conditions. Results showed that, in the proposed biorefinery concept, the energy from stillage anaerobic digestion accounted for approximately $30 \%$ of the overall energy production; further process improvement could be achieved by removing suspended solids from the input stream to the UASB reactor [130]. The frame of this work is not only the simple combination, but rather the integration of both bioethanol and biogas processes, which pursues the optimization of biochemical conversion pathways by lignocellulosic matter fractioning. 
Further development of this research resulted in the construction of one of the first integrated bioethanol/biogas plants, which was opened at Kalundborg, in Denmark in late 2009. It was designed to treat 30,000 t/year of biomass. The technology was used to produce a second generation ethanol from either the enzymatic fermentation of C6 sugars or the use of advanced yeast to convert a mixture of both C5 and C6 sugars. Ethanol yields were in the range 200-280 L/ton of dry straw: this product as well as the lignin separated from the incoming substrate were sold as fuels to other companies [131]. The development of this technology will be used, along with an innovative enzymatic product, within the Maabjerg Energy Concept, with the aim of producing second generation bio-ethanol, based on 300,000 tons of straw [132].

\section{The Use of Digestate for Bioethanol Production}

A further viable option for the combination of bioethanol fermentation and anaerobic digestion processes consists of the use of the anaerobic effluent as substrate for ethanol production. The anaerobic digestion residue, also known as digestate, is a mixture of partially degraded organic matter, microbial biomass and inorganic compounds. It is characterized by high potential fertiliser value due to its contents of nitrogen, phosphorous, potassium and micronutrients [133]. The agricultural use of the anaerobic digestate has not been clearly regulated yet [134], so that its aerobic processing has become a current practise $[135,136]$ to produce compost, which is commonly used as fertilizer. However the application on soil of waste-produced compost may turn to be not sustainable, due to the risk associated to the presence of potentially toxic compounds [137]. This condition requires the identification of further options to manage anaerobic digestion residues.

Despite its potential as fertilizer, the digestate still contains undigested solids, which can be either used to recover additional methane [138] or to produce ethanol [139]. The use of digestate as bioethanol production substrate appears a suitable strategy to handle the anaerobic residues properly as well as to provide a competitive supply of biomass for biofuel production.

Teater et al. [140] compared the bioethanol potential of switch-grass, corn stover and anaerobic digestion fiber from a commercial CSTR, treating dairy manure. The digestion fiber was obtained as the solid digestate after liquid/solid separation. The substrates were pretreated using an autoclave at different sodium hydroxide concentrations $(0.5-3 \mathrm{wt} . \%)$, two retention times $(1-3 \mathrm{~h})$, and two temperatures $\left(120{ }^{\circ} \mathrm{C}\right.$ and $\left.130{ }^{\circ} \mathrm{C}\right)$. Although comparable ethanol conversion efficiencies were observed, the use of digestate could offer some advantages, including: (i) the possibility of removing the size reduction unit from the bioethanol process; (ii) a low presence of pentose, whose fermentation raises operating issues in bioethanol production process; (iii) the relevant quantity and year round availability of cattle manure that could solve the logistical storage problems associated with annual crops, commonly destined to bioethanol production.

The bioethanol potential of the fiber originating from the anaerobic co-digestion of corn stover and swine manure, at different ratios, was also investigated [141]. At a stover-to-manure ratio of 40:60 the highest performances were observed both in terms of methane $(152 \mathrm{~g} / \mathrm{kg}$ dry raw feed) and ethanol ( $50 \mathrm{~g} / \mathrm{kg}$ dry raw feed) yields. The resulting net energy was estimated to be $5.5 \mathrm{MJ} / \mathrm{kg}$ of dry raw feed.

Anaerobic digestion effluent can also be used to replace freshwater and nutrients for bioethanol production: when co-fermented with wheat, ethanol concentration can be up to $18 \%$ higher in 
comparison to the production in freshwater. The enhanced bioethanol production was ascribed to the synergistic effect of nutrients, anaerobes, biochemical processing and enzymes in the anaerobic digestion effluent [142].

The outcomes of these studies are particularly interesting as they introduce further options to take greater advantage of the bioenergy potential of biomass feedstock, by integrating both anaerobic digestion and ethanol fermentation process under different operating conditions. However the number of reports is still limited and does not allow the generalization of results, which requires further studies.

\section{Conclusions}

Biomass is a versatile and abundant resource, which can be used to produce energy via different routes, including fermentation and anaerobic digestion. Several kinds of biomass can be used either to produce bioethanol or biogas and, although widely debated in scientific literature, it is not currently possible to state which is the best treatment option for a given substrate. To this end some boundary conditions, including the area of application and the presence of existing infrastructure, have to be previously identified.

As the transport sector accounts for the largest part of the world primary energy consumption, the production of bioethanol from biomass fermentation is gaining great interest. However the process spread on industrial scale is often limited by its low economic competitiveness with energy production processes based on the use of fossil fuels. Such aspect is mainly related to the high energy requirements to treat the biomass before the fermentation step as well as to the management of the stillage originating from the separation of ethanol concentrated solution from water.

This review highlighted that the combination of both bioethanol and anaerobic digestion has been identified as a valuable option to overcome these limits. The anaerobic processing of stillage can indeed solve the issue of managing bioethanol fermentation by-products while producing energy to fulfil the requirements of the facility. Moreover experimental results point out that fermentation acts as biomass pretreatment, so that the energy required to convert stillage into biogas via anaerobic digestion is lower than the one necessary to treat the whole substrate. The synergistic combination of both bioethanol and biogas production processes results in the optimization of the energy balance of single processes as well as in the possibility of taking greater advantage of biomass energetic potential.

Based on the latter statement the use of digestate as bioethanol fermentation substrate has also been studied. In this case the full exploitation of biomass energy was pursued along with the identification of a strategy to handle the anaerobic residues while providing a competitive supply of biomass for biofuel production. However further research is required in this field, with the aim of both enhancing knowledge on the weakness and strengths of the combined anaerobic digestion/fermentation process and identifying a proper option to manage bioethanol by-products from digestate fermentation. Conversely, the inverse process represents a successful treatment option.

The proposed review showed that anaerobic digestion can convert up to $80 \%$ of stillage COD into biogas. Organic loading rate higher than $10 \mathrm{gvs} / \mathrm{L} \mathrm{d}$ as well as hydraulic retention time as high as 6 days can be applied, but either operating strategies or system monitoring has to be considered to limit potentially inhibitory phenomena. In this context common issues are related to both ammonia and sulphur accumulation, which in turn depend on the use of nitrogen- or sulphur-rich stillage, respectively. 
Although the supply of trace metals can promote the correct development of the anaerobic process, it can turn to be not economically feasible, especially when considering full-scale operation. In order to ensure the stability of the anaerobic process, co-digestion could provide a proper solution. Further research is thus needed to identify the optimal combination of different substrates, taking into account not only the proper balance of chemical-physical properties, but also the simultaneous availability of substrates themselves.

Although both bioethanol fermentation and anaerobic digestion are reliable techniques, already common at full-scale, the integrated process feasibility for industrial application should be more deeply investigated. Reviewed literature highlights uncertain net energy gain as well as process stability issue, mainly dependent on the kind of feedstock. Further research should be thus addressed towards: (i) the characterization of different kinds of stillage according to its production process; (ii) the use of models to predict anaerobic digestion yields from stillage; (iii) the integrated bioethanol/biogas process investigation at larger scale, under continuous feed conditions, aimed at (iv) the development of both mass and energy balance.

Different considerations can be drawn when the use of lignocellulosic feedstocks is considered: the production of second generation ethanol, along with biogas and lignin, sold as fuels to power plants, has already been realised in Denmark. The effective integration of bioethanol and biogas processes was firstly performed in a demo-scale plant and then further developed as industrial project, pointing out the technical and economic feasibility of using waste biomass for a sustainable energy production.

\section{Acknowledgments}

This work was performed at the Department of Civil Engineering of Salerno University under Research Contract n. Rep. 1609 prot. 63565.

\section{Author Contributions}

Alessandra Cesaro carried out the analysis of scientific literature and prepared the manuscript; Vincenzo Belgiorno supervised the literature analysis and reviewed the final draft.

\section{Conflicts of Interest}

The authors declare no conflict of interest.

\section{References}

1. Maity, S.K. Opportunities, recent trends and challenges of integrated biorefinery: Part I. Renew. Sustain. Energy Rev. 2015, 43, 1427-1445.

2. Nigam, P.S.; Singh, A. Production of liquid biofuels from renewable resources. Prog. Energy Combust. Sci. 2011, 37, 52-68.

3. Bazmi, A.A.; Zahedi, G. Sustainable energy systems: Role of optimization modeling techniques in power generation and supply-A review. Renew. Sustain. Energy Rev. 2011, 15, 3480-3500.

4. Cucchiella, F.; D’Adamo, I. Issue on supply chain of renewable energy. Energy Convers. Manag. 2013, 76, 774-780. 
5. Long, H.; Li, X.; Wang, H.; Jia, J. Biomass resources and their bioenergy potential estimation: A review. Renew. Sustain. Energy Rev. 2013, 26, 344-352.

6. Angelis-Dimakis, A.; Biberacher, M.; Dominguez, J.; Fiorese, G.; Gadocha, S.; Gnansounou, E.; Guariso, G.; Kartalidis, A.; Panichelli, L.; Pinedo, I.; et al. Methods and tools to evaluate the availability of renewable energy sources. Renew. Sustain. Energy Rev. 2011, 15, 1182-1200.

7. Gabrielle, B.; Bamière, L.; Caldes, N.; De Cara, S.; Decocq, G.; Ferchaud, F.; Loyce, C.; Pelzer, E.; Perez, Y.; Wohlfahrt, J.; et al. Paving the way for sustainable bioenergy in Europe: Technological options and research avenues for large-scale biomass feedstock supply. Renew. Sustain. Energy Rev. 2014, 33, 11-25.

8. Chadwick, D.T.; McDonnell, K.P.; Brennan, L.P.; Fagan, C.C.; Everard, C.D. Evaluation of infrared techniques for the assessment of biomass and biofuel quality parameters and conversion technology processes: A review. Renew. Sustain. Energy Rev. 2014, 30, 672-681.

9. Fiorese, G.; Catenacci, M.; Bosetti, V.; Verdolini, E. The power of biomass: Experts disclose the potential for success of bioenergy technologies. Energy Policy 2014, 65, 94-114.

10. Tekin, K.; Karagöz, S.; Bektaş, S. A review of hydrothermal biomass processing. Renew. Sustain. Energy Rev. 2014, 40, 673-687.

11. Khan, A.A.; de Jong, W.; Jansens, P.J.; Spliethoff, H. Biomass combustion in fluidized bed boilers: Potential problems and remedies. Fuel Process. Technol. 2009, 90, 21-50.

12. Ward, J.; Rasul, M.G.; Bhuiya, M.M.K. Energy Recovery from Biomass by Fast Pyrolysis. Procedia Eng. 2014, 90, 669-674.

13. Abnisa, F.; Wan Daud, W.M.A. A review on co-pyrolysis of biomass: An optional technique to obtain a high-grade pyrolysis oil. Energy Convers. Manag. 2014, 87, 71-85.

14. Albertazzi, S.; Basile, F.; Brandin, J.; Einvall, J.; Hulteberg, C.; Fornasari, G.; Rosetti, V.; Sanati, M.; Trifirò, F.; Vaccari, A. The technical feasibility of biomass gasification for hydrogen production. Catal. Today 2005, 106, 297-300.

15. Batidzirai, B.; Mignot, A.P.R.; Schakel, W.B.; Junginger, H.M.; Faaij, A.P.C. Biomass torrefaction technology: Techno-economic status and future prospects. Energy 2013, 62, 196-214.

16. Van der Stelt, M.J.C.; Gerhauser, H.; Kiel, J.H.A.; Ptasinski, K.J. Biomass upgrading by torrefaction for the production of biofuels: A review. Biomass Bioenergy 2011, 35, 3748-3762.

17. Elliott, D.C.; Biller, P.; Ross, A.B.; Schmidt, A.J.; Jones, S.B. Hydrothermal liquefaction of biomass: Developments from batch to continuous process. Bioresour. Technol. 2015, 178, 147-156.

18. Brand, S.; Kim, J. Liquefaction of major lignocellulosic biomass constituents in supercritical ethanol. Energy 2015, 80, 64-74.

19. Srirangan, K.; Akawi, L.; Moo-Young, M.; Chou, C.P. Towards sustainable production of clean energy carriers from biomass resources. Appl. Energy 2012, 100, 172-186.

20. Kumar, A.; Kumar, N.; Baredar, P.; Shukla, A. A review on biomass energy resources, potential, conversion and policy in India. Renew. Sustain. Energy Rev. 2015, 45, 530-539.

21. Cherubini, F. The biorefinery concept: Using biomass instead of oil for producing energy and chemicals. Energy Convers. Manag. 2010, 51, 1412-1421.

22. Nallathambi Gunaseelan, V. Anaerobic digestion of biomass for methane production: A review. Biomass Bioenergy 1997, 13, 83-114. 
23. Ward, A.J.; Lewis, D.M.; Green, F.B. Anaerobic digestion of algae biomass: A review. Algal Res. 2014, 5, 204-214.

24. Morales, M.; Quintero, J.; Conejeros, R.; Aroca, G. Life cycle assessment of lignocellulosic bioethanol: Environmental impacts and energy balance. Renew. Sustain. Energy Rev. 2015, 42, 1349-1361.

25. Manzetti, S.; Andersen, O. A review of emission products from bioethanol and its blends with gasoline. Background for new guidelines for emission control. Fuel 2015, 140, 293-301.

26. Yue, D.; You, F.; Snyder, S.W. Biomass-to-bioenergy and biofuel supply chain optimization: Overview, key issues and challenges. Comput. Chem. Eng. 2014, 66, 36-56.

27. Posada, J.A.; Patel, A.D.; Roes, A.; Blok, K.; Faaij, A.P.C.; Patel, M.K. Potential of bioethanol as a chemical building block for biorefineries: Preliminary sustainability assessment of 12 bioethanol-based products. Bioresour. Technol. 2013, 135, 490-499.

28. Sarkar, N.; Ghosh, S.K.; Bannerjee, S.; Aikat, K. Bioethanol production from agricultural wastes: An overview. Renew. Energy 2012, 37, 19-27.

29. Weiland, P. Biogas production: current state and perspectives. Appl. Microbiol. Biotechnol. 2010, $85,849-860$.

30. Oleskowicz-Popiel, P.; Kádár, Z.; Heiske, S.; Klein-Marcuschamer, D.; Simmons, B.A.; Blanch, H.W.; Schmidt, J.E. Co-production of ethanol, biogas, protein fodder and natural fertilizer in organic farming - Evaluation of a concept for a farm-scale biorefinery. Bioresour. Technol. 2012, 104, 440-446.

31. Parajuli, R.; Dalgaard, T.; Jørgensen, U.; Adamsen, A.P.S.; Knudsen, M.T.; Birkved, M.; Gylling, M.; Schjørring, J.K. Biorefining in the prevailing energy and materials crisis: A review of sustainable pathways for biorefinery value chains and sustainability assessment methodologies. Renew. Sustain. Energy Rev. 2015, 43, 244-263.

32. Martin, M.; Svensson, N.; Fonseca, J.; Eklund, M. Quantifying the environmental performance of integrated bioethanol and biogas production. Renew. Energy 2014, 61, 109-116.

33. Balat, M. Production of bioethanol from lignocellulosic materials via the biochemical pathway: A review. Energy Convers. Manag. 2011, 52, 858-875.

34. Scott, F.; Venturini, F.; Aroca, G.; Conejeros, R. Selection of process alternatives for lignocellulosic bioethanol production using a MILP approach. Bioresour. Technol. 2013, 148, 525-534.

35. Limayem, A.; Ricke, S.C. Lignocellulosic biomass for bioethanol production: Current perspectives, potential issues and future prospects. Prog. Energy Combust. Sci. 2012, 38, 449-467.

36. Saxena, R.C.; Adhikari, D.K.; Goyal, H.B. Biomass-based energy fuel through biochemical routes: A review. Renew. Sustain. Energy Rev. 2009, 13, 167-178.

37. Lin, Y.; Zhang, W.; Li, C.; Sakakibara, K.; Tanaka, S.; Kong, H. Factors affecting ethanol fermentation using Saccharomyces cerevisiae BY4742. Biomass Bioenergy 2012, 47, 395-401.

38. De Souza, C.J.A.; Costa, D.A.; Rodrigues, M.Q.R.B.; dos Santos, A.F.; Lopes, M.R.; Abrantes, A.B.P.; dos Santos Costa, P.; Silveira, W.B.; Passos, F.M.L.; Fietto, L.G. The influence of presaccharification, fermentation temperature and yeast strain on ethanol production from sugarcane bagasse. Bioresour. Technol. 2012, 109, 63-69.

39. Dragone, G.; Silva, D.P.; de Almeida e Silva, J.B. Factors influencing ethanol production rates at high-gravity brewing. LWT-Food Sci. Technol. 2004, 37, 797-802. 
40. Wang, P.-M.; Zheng, D.-Q.; Chi, X.-Q.; Li, O.; Qian, C.-D.; Liu, T.-Z.; Zhang, X.-Y.; Du, F.-G.; Sun, P.-Y.; Qu, A.-M.; et al. Relationship of trehalose accumulation with ethanol fermentation in industrial Saccharomyces cerevisiae yeast strains. Bioresour. Technol. 2014, 152, 371-376.

41. Alkasrawi, M.; Abu Jrai, A.; Al-Muhtaseb, A.H. Simultaneous saccharification and fermentation process for ethanol production from steam-pretreated softwood: Recirculation of condensate streams. Chem. Eng. J. 2013, 225, 574-579.

42. Fujimoto, S.; Yanagida, T.; Nakaiwa, M.; Tatsumi, H.; Minowa, T. Pinch analysis for bioethanol production process from lignocellulosic biomass. Appl. Therm. Eng. 2011, 31, 3332-3336.

43. Haghighi Mood, S.; Hossein Golfeshan, A.; Tabatabaei, M.; Salehi Jouzani, G.; Najafi, G.H.; Gholami, M.; Ardjmand, M. Lignocellulosic biomass to bioethanol, a comprehensive review with a focus on pretreatment. Renew. Sustain. Energy Rev. 2013, 27, 77-93.

44. Tan, I.S.; Lee, K.T. Enzymatic hydrolysis and fermentation of seaweed solid wastes for bioethanol production: An optimization study. Energy 2014, 78, 53-62.

45. Doan, Q.C.; Moheimani, N.R.; Mastrangelo, A.J.; Lewis, D.M. Microalgal biomass for bioethanol fermentation: Implications for hypersaline systems with an industrial focus. Biomass Bioenergy 2012, 46, 79-88.

46. Vohra, M.; Manwar, J.; Manmode, R.; Padgilwar, S.; Patil, S. Bioethanol production: Feedstock and current technologies. J. Environ. Chem. Eng. 2014, 2, 573-584.

47. Carrier, M.; Loppinet-Serani, A.; Denux, D.; Lasnier, J.-M.; Ham-Pichavant, F.; Cansell, F.; Aymonier, C. Thermogravimetric analysis as a new method to determine the lignocellulosic composition of biomass. Biomass Bioenergy 2011, 35, 298-307.

48. Yang, L.; Xu, F.; Ge, X.; Li, Y. Challenges and strategies for solid-state anaerobic digestion of lignocellulosic biomass. Renew. Sustain. Energy Rev. 2015, 44, 824-834.

49. Bruni, E.; Jensen, A.P.; Pedersen, E.S.; Angelidaki, I. Anaerobic digestion of maize focusing on variety, harvest time and pretreatment. Appl. Energy 2010, 87, 2212-2217.

50. Khoo, H.H. Review of bio-conversion pathways of lignocellulose-to-ethanol: Sustainability assessment based on land footprint projections. Renew. Sustain. Energy Rev. 2015, 46, 100-119.

51. Mariano, A.P.; Dias, M.O.S.; Junqueira, T.L.; Cunha, M.P.; Bonomi, A.; Filho, R.M. Utilization of pentoses from sugarcane biomass: Techno-economics of biogas vs. butanol production. Bioresour. Technol. 2013, 142, 390-399.

52. Divya, D.; Gopinath, L.R.; Merlin Christy, P. A review on current aspects and diverse prospects for enhancing biogas production in sustainable means. Renew. Sustain. Energy Rev. 2015, 42, 690-699.

53. Cesaro, A.; Belgiorno, V. Pretreatment methods to improve anaerobic biodegradability of organic municipal solid waste fractions. Chem. Eng. J. 2014, 240, 24-37.

54. Kothari, R.; Pandey, A.K.; Kumar, S.; Tyagi, V.V.; Tyagi, S.K. Different aspects of dry anaerobic digestion for bio-energy: An overview. Renew. Sustain. Energy Rev. 2014, 39, 174-195.

55. Yan, Z.; Song, Z.; Li, D.; Yuan, Y.; Liu, X.; Zheng, T. The effects of initial substrate concentration, $\mathrm{C} / \mathrm{N}$ ratio, and temperature on solid-state anaerobic digestion from composting rice straw. Bioresour. Technol. 2015, 177, 266-273.

56. Zhang, C.; Su, H.; Baeyens, J.; Tan, T. Reviewing the anaerobic digestion of food waste for biogas production. Renew. Sustain. Energy Rev. 2014, 38, 383-392. 
57. El-Mashad, H.M.; Zeeman, G.; van Loon, W.K.P.; Bot, G.P.A.; Lettinga, G. Effect of temperature and temperature fluctuation on thermophilic anaerobic digestion of cattle manure. Bioresour. Technol. 2004, 95, 191-201.

58. Kim, J.K.; Oh, B.R.; Chun, Y.N.; Kim, S.W. Effects of temperature and hydraulic retention time on anaerobic digestion of food waste. J. Biosci. Bioeng. 2006, 102, 328-332.

59. Deng, L.; Yang, H.; Liu, G.; Zheng, D.; Chen, Z.; Liu, Y.; Pu, X.; Song, L.; Wang, Z.; Lei, Y. Kinetics of temperature effects and its significance to the heating strategy for anaerobic digestion of swine wastewater. Appl. Energy 2014, 134, 349-355.

60. Chae, K.J.; Jang, A.; Yim, S.K.; Kim, I.S. The effects of digestion temperature and temperature shock on the biogas yields from the mesophilic anaerobic digestion of swine manure. Bioresour. Technol. 2008, 99, 1-6.

61. Noutsopoulos, C.; Mamais, D.; Antoniou, K.; Avramides, C.; Oikonomopoulos, P.; Fountoulakis, I. Anaerobic co-digestion of grease sludge and sewage sludge: The effect of organic loading and grease sludge content. Bioresour. Technol. 2013, 131, 452-459.

62. Gou, C.; Yang, Z.; Huang, J.; Wang, H.; Xu, H.; Wang, L. Effects of temperature and organic loading rate on the performance and microbial community of anaerobic co-digestion of waste activated sludge and food waste. Chemosphere 2014, 105, 146-151.

63. Esposito, G.; Frunzo, L.; Panico, A.; Pirozzi, F. Modelling the effect of the OLR and OFMSW particle size on the performances of an anaerobic co-digestion reactor. Process Biochem. 2011, 46, $557-565$.

64. Wijekoon, K.C.; Visvanathan, C.; Abeynayaka, A. Effect of organic loading rate on VFA production, organic matter removal and microbial activity of a two-stage thermophilic anaerobic membrane bioreactor. Bioresour. Technol. 2011, 102, 5353-5360.

65. Motte, J.-C.; Escudié, R.; Bernet, N.; Delgenes, J.-P.; Steyer, J.-P.; Dumas, C. Dynamic effect of total solid content, low substrate/inoculum ratio and particle size on solid-state anaerobic digestion. Bioresour. Technol. 2013, 144, 141-148.

66. Kafle, G.K.; Bhattarai, S.; Kim, S.H.; Chen, L. Effect of feed to microbe ratios on anaerobic digestion of Chinese cabbage waste under mesophilic and thermophilic conditions: Biogas potential and kinetic study. J. Environ. Manage. 2014, 133, 293-301.

67. Kawai, M.; Nagao, N.; Tajima, N.; Niwa, C.; Matsuyama, T.; Toda, T. The effect of the labile organic fraction in food waste and the substrate/inoculum ratio on anaerobic digestion for a reliable methane yield. Bioresour. Technol. 2014, 157, 174-180.

68. Labatut, R.A.; Angenent, L.T.; Scott, N.R. Biochemical methane potential and biodegradability of complex organic substrates. Bioresour. Technol. 2011, 102, 2255-2264.

69. Sawatdeenarunat, C.; Surendra, K.C.; Takara, D.; Oechsner, H.; Khanal, S.K. Anaerobic digestion of lignocellulosic biomass: Challenges and opportunities. Bioresour. Technol. 2015, 178, 178-186.

70. Chandra, R.; Takeuchi, H.; Hasegawa, T. Methane production from lignocellulosic agricultural crop wastes: A review in context to second generation of biofuel production. Renew. Sustain. Energy Rev. 2012, 16, 1462-1476.

71. Davidsson, Å.; Gruvberger, C.; Christensen, T.H.; Hansen, T.L.; Jansen, J.C. Methane yield in source-sorted organic fraction of municipal solid waste. Waste Manag. 2007, 27, 406-414. 
72. Iroba, K.L.; Tabil, L.G.; Sokhansanj, S.; Dumonceaux, T. Pretreatment and fractionation of barley straw using steam explosion at low severity factor. Biomass Bioenergy 2014, 66, 286-300.

73. Sapci, Z. The effect of microwave pretreatment on biogas production from agricultural straws. Bioresour. Technol. 2013, 128, 487-494.

74. Xu, F.; Wang, Z.-W.; Li, Y. Predicting the methane yield of lignocellulosic biomass in mesophilic solid-state anaerobic digestion based on feedstock characteristics and process parameters. Bioresour. Technol. 2014, 173, 168-176.

75. Mayer, F.; Gerin, P.A.; Noo, A.; Foucart, G.; Flammang, J.; Lemaigre, S.; Sinnaeve, G.; Dardenne, P.; Delfosse, P. Assessment of factors influencing the biomethane yield of maize silages. Bioresour. Technol. 2014, 153, 260-268.

76. Kačík, F.; Šmíra, P.; Kačíková, D.; Vel'ková, V.; Nasswettrová, A.; Vacek, V. Chemical alterations of pine wood saccharides during heat sterilisation. Carbohydr. Polym. 2015, 117, 681-686.

77. Gao, J.; Chen, L.; Yuan, K.; Huang, H.; Yan, Z. Ionic liquid pretreatment to enhance the anaerobic digestion of lignocellulosic biomass. Bioresour. Technol. 2013, 150, 352-358.

78. Szczerbowski, D.; Pitarelo, A.P.; Zandoná Filho, A.; Ramos, L.P. Sugarcane biomass for biorefineries: Comparative composition of carbohydrate and non-carbohydrate components of bagasse and straw. Carbohydr. Polym. 2014, 114, 95-101.

79. Ji, W.; Shen, Z.; Wen, Y. Hydrolysis of wheat straw by dilute sulfuric acid in a continuous mode. Chem. Eng. J. 2015, 260, 20-27.

80. Bateni, H.; Karimi, K.; Zamani, A.; Benakashani, F. Castor plant for biodiesel, biogas, and ethanol production with a biorefinery processing perspective. Appl. Energy 2014, 136, 14-22.

81. Moshi, A.P.; Crespo, C.F.; Badshah, M.; Hosea, K.M.M.; Mshandete, A.M.; Elisante, E.; Mattiasson, B. Characterisation and evaluation of a novel feedstock, Manihot glaziovii, Muell. Arg, for production of bioenergy carriers: Bioethanol and biogas. Bioresour. Technol. 2014, 172, $58-67$.

82. Gonela, V.; Zhang, J. Design of the optimal industrial symbiosis system to improve bioethanol production. J. Clean. Prod. 2014, 64, 513-534.

83. Taheripour, F.; Hertel, T.W.; Tyner, W.E.; Beckman, J.F.; Birur, D.K. Biofuels and their by-products: Global economic and environmental implications. Biomass Bioenergy 2010, 34, 278-289.

84. Latif, M.A.; Mehta, C.M.; Batstone, D.J. Low pH anaerobic digestion of waste activated sludge for enhanced phosphorous release. Water Res. 2015, 81, 288-293.

85. Riggio, V.; Comino, E.; Rosso, M. Energy production from anaerobic co-digestion processing of cow slurry, olive pomace and apple pulp. Renew. Energy 2015, 83, 1043-1049.

86. Maspolim, Y.; Zhou, Y.; Guo, C.; Xiao, K.; Ng, W.J. Comparison of single-stage and two-phase anaerobic sludge digestion systems-Performance and microbial community dynamics. Chemosphere 2015, 140, 54-62.

87. Tian, Z.; Mohan, G.R.; Ingram, L.; Pullammanappallil, P. Anaerobic digestion for treatment of stillage from cellulosic bioethanol production. Bioresour. Technol. 2013, 144, 387-395.

88. Mustafa, A.F.; McKinnon, J.J.; Christensen, D.A. Chemical characterization and in vitro crude protein degradability of thin stillage derived from barley- and wheat-based ethanol production. Anim. Feed Sci. Technol. 1999, 80, 247-256. 
89. Wilkie, A.C.; Riedesel, K.J.; Owens, J.M. Stillage characterization and anaerobic treatment of ethanol stillage from conventional and cellulosic feedstocks. Biomass Bioenergy 2000, 19, 63-102.

90. Wang, W.; Xie, L.; Luo, G.; Zhou, Q. Enhanced fermentative hydrogen production from cassava stillage by co-digestion: The effects of different co-substrates. Int. J. Hydrog. Energy 2013, 38, 6980-6988.

91. Kim, Y.; Mosier, N.S.; Hendrickson, R.; Ezeji, T.; Blaschek, H.; Dien, B.; Cotta, M.; Dale, B.; Ladisch, M.R. Composition of corn dry-grind ethanol by-products: DDGS, wet cake, and thin stillage. Bioresour. Technol. 2008, 99, 5165-5176.

92. Wang, K.; Zhang, J.; Tang, L.; Zhang, H.; Zhang, G.; Yang, X.; Liu, P.; Mao, Z. Establishment and assessment of a novel cleaner production process of corn grain fuel ethanol. Bioresour. Technol. 2013, 148, 453-460.

93. Krzywonos, M.; Cibis, E.; Miśkiewicz, T.; Ryznar-Luty, A. Utilization and biodegradation of starch stillage (distillery wastewater). Electron. J. Biotechnol. 2009, 12, doi:10.2225/vol12-issue1fulltext-5.

94. Moraes, B.S.; Zaiat, M.; Bonomi, A. Anaerobic digestion of vinasse from sugarcane ethanol production in Brazil: Challenges and perspectives. Renew. Sustain. Energy Rev. 2015, 44, 888-903.

95. Kaparaju, P.; Serrano, M.; Angelidaki, I. Optimization of biogas production from wheat straw stillage in UASB reactor. Appl. Energy 2010, 87, 3779-3783.

96. Krzywonos, M.; Cibis, E.; Ryznar-Luty, A.; Miśkiewicz, T.; Borowiak, D. Aerobic biodegradation of wheat stillage (distillery wastewater) at an elevated temperature-Effect of solids separation. Biochem. Eng. J. 2010, 49, 1-6.

97. Cesaro, A.; Velten, S.; Belgiorno, V.; Kuchta, K. Enhanced anaerobic digestion by ultrasonic pretreatment of organic residues for energy production. J. Clean. Prod. 2014, 74, 119-124.

98. Park, J.-H.; Yoon, J.-J.; Park, H.-D.; Lim, D.J.; Kim, S.-H. Anaerobic digestibility of algal bioethanol residue. Bioresour. Technol. 2012, 113, 78-82.

99. Park, J.-H.; Kim, S.-H.; Park, H.-D.; Lim, D.J.; Yoon, J.-J. Feasibility of anaerobic digestion from bioethanol fermentation residue. Bioresour. Technol. 2013, 141, 177-183.

100. Luo, G.; Xie, L.; Zou, Z.; Wang, W.; Zhou, Q.; Shim, H. Anaerobic treatment of cassava stillage for hydrogen and methane production in continuously stirred tank reactor (CSTR) under high organic loading rate (OLR). Int. J. Hydrog. Energy 2010, 35, 11733-11737.

101. Westerholm, M.; Hansson, M.; Schnürer, A. Improved biogas production from whole stillage by co-digestion with cattle manure. Bioresour. Technol. 2012, 114, 314-319.

102. Andalib, M.; Hafez, H.; Elbeshbishy, E.; Nakhla, G.; Zhu, J. Treatment of thin stillage in a high-rate anaerobic fluidized bed bioreactor (AFBR). Bioresour. Technol. 2012, 121, 411-418.

103. Eskicioglu, C.; Kennedy, K.J.; Marin, J.; Strehler, B. Anaerobic digestion of whole stillage from dry-grind corn ethanol plant under mesophilic and thermophilic conditions. Bioresour. Technol. 2011, 102, 1079-1086.

104. Eskicioglu, C.; Ghorbani, M. Effect of inoculum/substrate ratio on mesophilic anaerobic digestion of bioethanol plant whole stillage in batch mode. Process Biochem. 2011, 46, 1682-1687.

105. Alkan-Ozkaynak, A.; Karthikeyan, K.G. Anaerobic digestion of thin stillage for energy recovery and water reuse in corn-ethanol plants. Bioresour. Technol. 2011, 102, 9891-9896. 
106. Nasr, N.; Elbeshbishy, E.; Hafez, H.; Nakhla, G.; Hesham El Naggar, M. Comparative assessment of single-stage and two-stage anaerobic digestion for the treatment of thin stillage. Bioresour. Technol. 2012, 111, 122-126.

107. Wang, Z.; Lv, Z.; Du, J.; Mo, C.; Yang, X.; Tian, S. Combined process for ethanol fermentation at high-solids loading and biogas digestion from unwashed steam-exploded corn stover. Bioresour. Technol. 2014, 166, 282-287.

108. Schmidt, T.; Pröter, J.; Scholwin, F.; Nelles, M. Anaerobic digestion of grain stillage at high organic loading rates in three different reactor systems. Biomass Bioenergy 2013, 55, 285-290.

109. Moestedt, J.; Nordell, E.; Schnürer, A. Comparison of operating strategies for increased biogas production from thin stillage. J. Biotechnol. 2014, 175, 22-30.

110. Schmidt, T.; Nelles, M.; Scholwin, F.; Pröter, J. Trace element supplementation in the biogas production from wheat stillage - Optimization of metal dosing. Bioresour. Technol. 2014, 168, 80-85.

111. Shakeri Yekta, S.; Lindmark, A.; Skyllberg, U.; Danielsson, Å.; Svensson, B.H. Importance of reduced sulfur for the equilibrium chemistry and kinetics of $\mathrm{Fe}(\mathrm{II}), \mathrm{Co}(\mathrm{II})$ and $\mathrm{Ni}$ (II) supplemented to semi-continuous stirred tank biogas reactors fed with stillage. J. Hazard. Mater. 2014, 269, 83-88.

112. Sun, Z.-Y.; Yamaji, S.; Cheng, Q.-S.; Yang, L.; Tang, Y.-Q.; Kida, K. Simultaneous decrease in ammonia and hydrogen sulfide inhibition during the thermophilic anaerobic digestion of protein-rich stillage by biogas recirculation and air supply at $60^{\circ} \mathrm{C}$. Process Biochem. 2014, 49, 2214-2219.

113. Patni, N.; Pillai, S.G.; Dwivedi, A.H. Wheat as a Promising Substitute of Corn for Bioethanol Production. Procedia Eng. 2013, 51, 355-362.

114. Dererie, D.Y.; Trobro, S.; Momeni, M.H.; Hansson, H.; Blomqvist, J.; Passoth, V.; Schnürer, A.; Sandgren, M.; Ståhlberg, J. Improved bio-energy yields via sequential ethanol fermentation and biogas digestion of steam exploded oat straw. Bioresour. Technol. 2011, 102, 4449-4455.

115. Zhang, Q.-H.; Lu, X.; Tang, L.; Mao, Z.-G.; Zhang, J.-H.; Zhang, H.-J.; Sun, F.-B. A novel full recycling process through two-stage anaerobic treatment of distillery wastewater for bioethanol production from cassava. J. Hazard. Mater. 2010, 179, 635-641.

116. Demirel, B.; Yenigün, O. Two-phase anaerobic digestion processes: A review. J. Chem. Technol. Biotechnol. 2002, 77, 743-755.

117. Kobayashi, T.; Tang, Y.; Urakami, T.; Morimura, S.; Kida, K. Digestion performance and microbial community in full-scale methane fermentation of stillage from sweet potato-shochu production. J. Environ. Sci. 2014, 26, 423-431.

118. Moestedt, J.; Påledal, S.N.; Schnürer, A.; Nordell, E. Biogas Production from Thin Stillage on an Industrial Scale-Experience and Optimisation. Energies 2013, 6, 5642-5655.

119. García-Gen, S.; Rodríguez, J.; Lema, J.M. Optimisation of substrate blends in anaerobic co-digestion using adaptive linear programming. Bioresour. Technol. 2014, 173, 159-167.

120. Hamawand, I. Anaerobic digestion process and bio-energy in meat industry: A review and a potential. Renew. Sustain. Energy Rev. 2015, 44, 37-51.

121. Mata-Alvarez, J.; Dosta, J.; Romero-Güiza, M.S.; Fonoll, X.; Peces, M.; Astals, S. A critical review on anaerobic co-digestion achievements between 2010 and 2013. Renew. Sustain. Energy Rev. 2014, 36, 412-427. 
122. Wang, W.; Xie, L.; Chen, J.; Luo, G.; Zhou, Q. Biohydrogen and methane production by co-digestion of cassava stillage and excess sludge under thermophilic condition. Bioresour. Technol. 2011, 102, 3833-3839.

123. Andalib, M.; Elbeshbishy, E.; Mustafa, N.; Hafez, H.; Nakhla, G.; Zhu, J. Performance of an anaerobic fluidized bed bioreactor (AnFBR) for digestion of primary municipal wastewater treatment biosolids and bioethanol thin stillage. Renew. Energy 2014, 71, 276-285.

124. Sharma, D.; Espinosa-Solares, T.; Huber, D.H. Thermophilic anaerobic co-digestion of poultry litter and thin stillage. Bioresour. Technol. 2013, 136, 251-256.

125. John, R.P.; Anisha, G.S.; Nampoothiri, K.M.; Pandey, A. Micro and macroalgal biomass: A renewable source for bioethanol. Bioresour. Technol. 2011, 102, 186-193.

126. Kemppainen, K.; Ranta, L.; Sipilä, E.; Östman, A.; Vehmaanperä, J.; Puranen, T.; Langfelder, K.; Hannula, J.; Kallioinen, A.; Siika-aho, M.; Sipilä, K.; von Weymarn, N. Ethanol and biogas production from waste fibre and fibre sludge - The FibreEtOH concept. Biomass Bioenergy 2012, 46, 60-69.

127. Narra, M.; Balasubramanian, V. Utilization of solid and liquid waste generated during ethanol fermentation process for production of gaseous fuel through anaerobic digestion-A zero waste approach. Bioresour. Technol. 2015, 180, 376-380.

128. Capecchi, L.; Galbe, M.; Barbanti, L.; Wallberg, O. Combined ethanol and methane production using steam pretreated sugarcane bagasse. Ind. Crops Prod. 2015, 74, 255-262.

129. Torry-Smith, M.; Sommer, P.; Ahring, B.K. Purification of bioethanol effluent in an UASB reactor system with simultaneous biogas formation. Biotechnol. Bioeng. 2003, 84, 7-12.

130. Uellendahl, H.; Ahring, B.K. Anaerobic digestion as final step of a cellulosic ethanol biorefinery: Biogas production from fermentation effluent in a UASB reactor-pilot-scale results. Biotechnol. Bioeng. 2010, 107, 59-64.

131. Global Solutions. Scale up history. Available online: http://www.inbicon.com/en/global-solutions (accessed on 20 July 2015).

132. Maabjerg Energy Concept. Status Report. Moving towards realization 2013. Available online: http://www.maabjergenergyconcept.eu/ (accessed on 20 July 2015).

133. Alburquerque, J.A.; de la Fuente, C.; Ferrer-Costa, A.; Carrasco, L.; Cegarra, J.; Abad, M.; Bernal, M.P. Assessment of the fertiliser potential of digestates from farm and agroindustrial residues. Biomass Bioenergy 2012, 40, 181-189.

134. Massaccesi, L.; Sordi, A.; Micale, C.; Cucina, M.; Zadra, C.; Di Maria, F.; Gigliotti, G. Chemical characterisation of percolate and digestate during the hybrid solid anaerobic digestion batch process. Process Biochem. 2013, 48, 1361-1367.

135. Abdullahi, Y.A.; Akunna, J.C.; White, N.A.; Hallett, P.D.; Wheatley, R. Investigating the effects of anaerobic and aerobic post-treatment on quality and stability of organic fraction of municipal solid waste as soil amendment. Bioresour. Technol. 2008, 99, 8631-8636.

136. Bustamante, M.A.; Restrepo, A.P.; Alburquerque, J.A.; Pérez-Murcia, M.D.; Paredes, C.; Moral, R.; Bernal, M.P. Recycling of anaerobic digestates by composting: effect of the bulking agent used. J. Clean. Prod. 2013, 47, 61-69.

137. Cesaro, A.; Belgiorno, V.; Guida, M. Compost from organic solid waste: Quality assessment and European regulations for its sustainable use. Resour. Conserv. Recycl. 2015, 94, 72-79. 
138. Menardo, S.; Gioelli, F.; Balsari, P. The methane yield of digestate: Effect of organic loading rate, hydraulic retention time, and plant feeding. Bioresour. Technol. 2011, 102, 2348-2351.

139. Yue, Z.; Teater, C.; Liu, Y.; MacLellan, J.; Liao, W. A sustainable pathway of cellulosic ethanol production integrating anaerobic digestion with biorefining. Biotechnol. Bioeng. 2010, 105, 1031-1039.

140. Teater, C.; Yue, Z.; MacLellan, J.; Liu, Y.; Liao, W. Assessing solid digestate from anaerobic digestion as feedstock for ethanol production. Bioresour. Technol. 2011, 102, 1856-1862.

141. MacLellan, J.; Chen, R.; Kraemer, R.; Zhong, Y.; Liu, Y.; Liao, W. Anaerobic treatment of lignocellulosic material to co-produce methane and digested fiber for ethanol biorefining. Bioresour. Technol. 2013, 130, 418-423.

142. Gao, T.; Li, X. Using thermophilic anaerobic digestate effluent to replace freshwater for bioethanol production. Bioresour. Technol. 2011, 102, 2126-2129.

(C) 2015 by the authors; licensee MDPI, Basel, Switzerland. This article is an open access article distributed under the terms and conditions of the Creative Commons Attribution license (http://creativecommons.org/licenses/by/4.0/). 